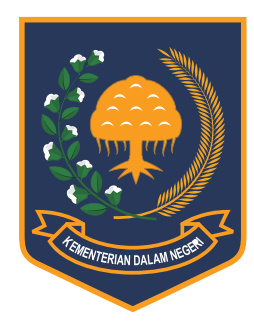

JURNAL BINA PRAJA

e-ISSN: 2503-3360 | p-ISSN: 2085-4323

Accreditation Number

21/E/KPT/2018

http://jurnal.kemendagri.go.id/index.php/jbp/index

\title{
Collaborative Governance IN CoRporate Social RESPONSIBILITY ForUM IN BANYUMAS REGENCY
}

\author{
Iqtikaful Furqoni*, Slamet Rosyadi, Alizar Isna \\ Jurusan Ilmu Administrasi Negara FISIP Universitas Jenderal Soedirman \\ Jl. Prof. Dr. H. R. Boenyamin 993 Purwokerto 53122
}

Received: 23 May 2019; Accepted: 2 September 2019; Published online: 8 November 2019

DOI: $10.21787 /$ jbp.11.2019.209-217

\begin{abstract}
This research is motivated by the SATRIA CSR (Corporate Social Responsibility) Forum in Banyumas Regency which involves various parties such as local governments, companies, academics, NGOs, and mass media that collaborate in supporting regional development through CSR. Therefore, this paper aims to describe in-depth the governance of the SATRIA CSR Forum in Banyumas Regency in the perspective of collaborative governance. This research uses a qualitative method with a phenomenological approach. The research location was in Banyumas Regency, with the target of the research consisting of government elements, private elements, mass media elements, NGOs, the community, and academics. The selection of informants was carried out using purposive sampling and snowball sampling techniques. The data analysis method used is the interactive analysis. The results found that the existence of internal and external dialogue was good initial progress in the governance of the SATRIA CSR Forum. Even so, there are still some aspects of CSR Forum governance that have not been maximized, such as stakeholder's commitment and the business community's understanding of CSR regulations. Therefore, efforts are needed to get the business community involved in the SATRIA CSR Forum. In this case, the role of local government is one of the keys for the business world to be involved, including by providing understanding to the business community regarding CSR regulations. The results of this study contribute to an understanding of the implementation of collaborative approaches in the context of CSR programs at the local level.
\end{abstract}

Keywords: Banyumas, Collaborative Governance, Corporate Social Responsibility, CSR Forum, Regional Development.

\section{INTRODUCTION}

Corporate Social Responsibility (CSR) is a commitment of the business community to contribute to sustainable economic development, but still taking into account the balance in economic, social, and environmental aspects (Zaidi, Surya, \& Juslan, 2016, p. 242). In general, many obstacles are still found in Indonesia in the implementation of CSR, such as the problem of costs, human resources, determination of targets, form and distribution of activities, licensing and regulation, lack of partnerships, activity dissemination, and lack of understanding of the implementation of CSR by companies (Azzahra, 2016). Similar problems in managing CSR also emerge at the regional level in Indonesia, many of the potentials for CSR in the area has not been explored and managed well. This can be seen from the potential of CSR in Banyumas that has not been fully managed optimally. Although there is already a Banyumas Regency Regulation Number 15 of 2015 regarding Corporate Social Responsibility regulating CSR, so far only about $2 \%$ of companies in Banyumas Regency have channeled CSR budgets through various programs or activities. The companies involved so far have also not been recorded and managed properly (Suara Merdeka, 2018). This is because CSR governance has not collaborated between various interrelated parties. If the potential can be explored to the fullest, it will greatly assist the development program, because, on the other hand, local governments have budget constraints in implementing regional development programs. As stated by the Coordinating Minister for Human Development and Culture (Menko PMK)

\footnotetext{
* Corresponding Author

Phone : +62 85777945898

Email : iqtikafulfurqon@gmail.com 
that the great potential for CSR budgets from private and state companies can be utilized to strengthen government's efforts to alleviate poverty and social development (Humas PMK, 2015).

Banyumas Regency currently has considerable CSR potential. Data from the Central Statistics Agency (BPS) of Banyumas Regency in 2018 shows that from 2014 to 2017, the number of businesses in the Banyumas Regency tended to increase. The number of businesses in Banyumas Regency in 2014 reached 577, in 2015 it increased to 622, in 2016 it continued to increase to 701, and in 2017 it amounted to 613 businesses. The amount consists of the business world in the form of limited liability companies, CV/Firm, cooperatives, and individuals. This figure can be seen as an opportunity that should involve more companies in CSR activities.

The potential of the CSR budget in Banyumas can be utilized as an effort to involve CSR to support the resolution of social problems. Moreover, Central Java Province BPS data for 2018 shows that Banyumas Regency ranks second after Brebes Regency as the Regency with the poorest population in Central Java, which is 226,20 thousand inhabitants. Seeing this, there is the potential to involve the business world through CSR to help solve existing social problems. For this reason, efforts need to be made through increased cooperation between the government and the private sector that is more systematic and sustainable. These efforts must be developed and optimized, including through CSR schemes (Machmud, 2015, p. 31).

Nevertheless, CSR governance in Banyumas Regency has not been optimally carried out. According to the Head of the People's Welfare Division of the Banyumas Regency Secretariat (Kabag Kesra Banyumas Regional Secretariat), CSR governance has not been optimized in Banyumas Regency because various companies have not been coordinated with local governments, communities and various other elements (personal communication, March 16, 2018). As a result, CSR programs run by businesses have the potential to overlap with local government programs. Therefore, it is necessary to synchronize the CSR program of the business world with the regional development agenda. The implementation of CSR in the regions must also be supported by various elements, such as regional governments, legal certainty, and a guarantee of social involvement (Lamo, 2017, p. 30). Thus, CSR Forum becomes important to be formed in Banyumas Regency which involves various parties, such as local governments, business world, academics, NGOs and mass organizations, as well as mass media that collaborate in supporting regional development through CSR.
As a form of response of the Banyumas Regency Government in overcoming CSR governance problems, in early 2018, the SATRIA CSR Forum was formed. CSR forum consists of elements that come from the community, companies, local governments, and academics with the knowledge, willingness, and ability to facilitate the implementation of corporate social responsibility programs or CSR. The SATRIA CSR Forum was formed through the Decree of the Banyumas Regent No. 460/137 of 2018 on the SATRIA Corporate Social Responsibility Forum in the Banyumas Regency of 2018-2021 Period. The Regent's Decree is an implementation of Banyumas Regent Regulation No. 77 of 2017 on Corporate Social Responsibility (CSR). However, at the beginning of the formation of the CSR Forum in Banyumas, there were still obstacles. The business world still has a different view and objection to being involved in the CSR Forum because it already has its program (Personal Communication with the Head of Kesra Banyumas Regional Secretariat, March 16, 2018). Although collaboration between various parties becomes important to do because based on the results of previous research conducted by Zain (2015), it found that there is a need for collaborative strategies between several parties, such as cooperating with NGOs and mass media in managing CSR. A research conducted by (Zaidi et al., 2016) also found that CSR programs that are synchronized with local government programs can sustain regional development. Similar research conducted by Hakim (2013) also recommends that CSR programs need to be integrated into government development planning programs. Thus in CSR Forum governance, the concept of collaborative governance can be developed so that citizens and the private sector can play an active role and have awareness, and take responsibility together with governments who are willing to be open, responsive, and willing to listen and want to actively involve themselves in programs or public assets governance.

Ansell \& Gash (2007, pp. 544-545) explained that collaborative governance is a controlling arrangement in which one or more public institutions and stakeholders are directly involved in a collective decision-making process that is formal, consensus-oriented, aims to make or establish public policies, and managing public programs or assets. The definition emphasizes seven important criteria, namely: (1) There are public, private, and community; (2) Non-state actors participate; (3) Income increases; (4) infrastructure development; (5) Officially organized and meet collectively; (6) Decisions of consensus; and (7) The focus of collaboration is on public policy or public 
governance. Therefore, this study aims to examine the governance of the SATRIA Corporate Social Responsibility Forum (CSR Forum) in Banyumas Regency with a collaborative governance approach. The results and discussion of the research are focused on the collaborative process that involves the interaction of aspects, such as face to face dialogue, trust building, commitment to process, shared understanding, intermediate outcomes. The interaction of these aspects determines the success of the collaboration process in the SATRIA CSR Forum in Banyumas Regency.

\section{METHOD}

The research method used is qualitative research with a phenomenological approach. This approach is used to understand the phenomena regarding the SATRIA CSR Forum in Banyumas Regency based on the experience and knowledge possessed by the research subjects, as well as to analyze the motives in the participation and experience of key informants in-depth (Hjern \& Porter, 1981, p. 223). The location of the study was in the Regency of Banyumas, with the reasons that: (1) Banyumas Regency is one of the Regency that currently has formed a CSR Forum as a new strategy in implementing CSR which is expected to be in synergy with the government, the community, and various parties in supporting development in Banyumas Regency; (2) The CSR Forum apparently still encountered several obstacles at the beginning, such as a disagreement between several parties. Seeing this, it is necessary to study the governance of CSR Forums in Banyumas Regency. The target of the research is the parties involved in the SATRIA CSR Forum consisting of government elements consisting of the People's Welfare Section of the Banyumas Regency Secretariat, the Banyumas Regency Bappelitbangda, the Labor Office, Cooperatives and SMEs of the Banyumas Regency, the Banyumas Regency Office of Environment, the Archives Office and Banyumas Regency Regional Library, private elements consisting of Semen Bima Ajibarang, REI Banyumas Commissariat, PT. CMMI Travel Purwokerto, elements of mass media consisting of Radio Mitra FM Purwokerto, elements of NGOs consisting of BAZNAS Banyumas Regency, Dompet Dhuafa Purwokerto, ORARI Banyumas Regency, the community, and academics originating from the lecturers of the Faculty of Economics and Business, Jenderal Soedirman University. The selection of informants uses purposive sampling and snowball sampling techniques. Data collection was carried out using in-depth interviews, observation, and documentation. To determine the data validity is by meeting the criteria of credibility, transferability, dependability, and confirmability (Moleong, 2015). While the data analysis method used is an interactive analysis method, which consists of data collection, data condensation, data display, and concluding (Miles, Huberman, \& Saldana, 2014, p. 10).

\section{RESULTS AND DISCUSSION}

CSR forums are elements that come from the community, companies, local governments, and academics who have the knowledge, willingness, and ability to facilitate the implementation of corporate social responsibility programs or CSR. The SATRIA CSR Forum in Banyumas Regency involves the following actors.

1. Banyumas Regency Government

The government actors involved are the Banyumas Regent, who is structurally a manager, and the Banyumas Regional Secretariat Welfare Division, who is the initiator of the formation of the SATRIA CSR Forum, and as the governance structure as a director. The SATRIA CSR Forum also involved representatives from each Regional Apparatus Organization (OPD) as partners of the SATRIA CSR Forum.

\section{Business World}

In the governance structure, SATRIA CSR Forum involves the business world such as Semen Bima Ajibarang, Cheer Cafe Purwokerto, Indonesian Real Estate (REI) Banyumas Commissariat, PT. Global Asa Sedesa, Noodle Company Tiga Anak, and CMMI Travel Purwokerto. In carrying out its program of activities, the SATRIA CSR Forum also involves a variety of businesses outside the governance structure.

\section{Mass Media}

The actor from the mass media involved in the SATRIA CSR Forum is Radio Mitra FM Purwokerto.

\section{Academics}

Academics in the SATRIA CSR Forum are Prayoga Pribadi, S.E, M.Sc from STIMIK Amikom, Purwokerto, and Dr. Refius Pradipta Setyanto, M.Si from Jenderal Soedirman University, Purwokerto.

5. NGOs and Community Based Organizations NGOs and CBOs involved include the Banyumas Regency BAZNAS, Dompet Dhuafa Purwokerto, and the Banyumas Local Organization.

\section{Collaborative Governance in Corporate Social Responsibility Forum




\section{Community}

The community is also involved in the SATRIA CSR Forum, namely as a program proponent and as a program recipient.

When viewed from the background of its regulations, the formation of the SATRIA CSR Forum is based on the Banyumas Regent Decree Number 460/137 of 2018 on the Corporate Social Responsibility Forum of the Banyumas Regency SATRIA of 2018-2021 period, which is a form of implementation of the Banyumas Regent Regulation Number 77 of 2017 on Corporate Social Responsibility (TJSP) chapter 11 Part 2 of Article 28, 29 , and 30. The vision of the SATRIA CSR Forum is "The realization of real participation in the business world to participate in building and prospering the Banyumas community through the implementation of coordinated and integrated corporate social responsibility (CSR)". To realize this vision, the SATRIA CSR Forum has five missions, as follows:

1. Perform cross-stakeholder coordination functions to equalize social welfare through targeted and integrated CSR programs.

2. Increase the awareness and participation of the business world in implementing corporate social responsibility.

3. Build the participation of the business community to make people independent to achieve social welfare

4. Increase synergy and cooperation that mutually benefit the local governments, the business community, and the community.

5. Develop activities and programs that are empowering, sustainable, and environmentally sound.

The above description shows that the SATRIA CSR Forum in Banyumas Regency involves many parties, namely local governments, the private sector, the mass media, NGOs and CBOs, as well as the community collaborating to achieve common goals. In this case, the government brought various stakeholders together in a forum with public institutions to engage in consensusoriented decision-making (Ansell \& Gash, 2007, p. 543). Rasche $(2010$, p. 14$)$ also explained that multistakeholder collaboration, as seen in the SATRIA CSR Forum, was built to support stronger institutional infrastructure to support corporate social responsibility or CSR. Thus, a theoretical perspective on collaborative governance can be used to explain the governance of the SATRIA CSR Forum, which is seen through the collaborative process as follows.

\section{A. Face to Face Dialogue}

Face to face dialogue is the earliest stage in the SATRIA CSR Forum to collaborate with various parties. In general, there is two face to face dialogue models found in the SATRIA CSR Forum, as follows:

\section{1) Face to Face Dialogue in The Internal Forum}

This form of dialogue runs routinely by involving all governance in the form of internal coordination meetings. Internal coordination meetings that have been held so far have discussed work programs, including making program catalogs, proposals offered to the business world, and internal organizational issues. However, the busyness of the stakeholders has become one of the causes of the involvement of the governance in the face-to-face dialogue. In fact, in collaborative governance stakeholders must meet together in a multilateral deliberation process (Ansell \& Gash, 2007 , p. 546). Therefore, if this is not immediately anticipated, it will continue to hamper collaboration in the SATRIA CSR Forum. This is consistent with the results of research conducted by Ervianti (2018, p. 11) who found that lack of coordination between parties was one of the factors that hindered the implementation of collaborative governance. Thus, governance restructuring is an alternative that can be implemented as a solution to anticipate the busy schedule of Committee.

\section{2) Face to Face Dialogue in With External Parties}

External parties involved are regional government and other parties not included in the governance structure. Meetings with local governments are carried out following the needs and the existing agenda. The meeting is related to the CSR Facilitation Team, whose members came from OPD representatives who were partners of the CSR Forum in carrying out cross-stakeholder coordination functions to equalize social welfare through targeted and integrated CSR programs. The face to face dialogue carried out by the CSR Forum also involved businesses in the Banyumas Regency in the form of a company visit. Company visit activities are carried out with the target of companies in Banyumas Regency. The activity is an effort to invite the business community to carry out CSR activities involving CSR Forums. This is done so that the activities carried out are in line with the needs of the community and local government. Unfortunately, the company visit only runs at the beginning of governance. Therefore, company visit activities need to be carried out on an ongoing basis because face to face dialogue is the heart of building 
trust (Ansell \& Gash, 2007, p. 558).

The description can illustrate that the form of face-to-face dialogue carried out by the SATRIA CSR Forum is carried out by involving internal and external governance. This shows a good first step in the collaborative process. Cross-sector collaboration has the potential to succeed when they communicate with stakeholders, both internal and external, as the legitimacy of cooperation, as a form of organization, as a separate entity, as well as a reliable source of interaction between members (Bryson \& Crosby, 2006, p. 47).

Face to face dialogue in the SATRIA CSR Forum is also a media to negotiate from various parties that aim to produce a mutual agreement. All parties involved in the CSR Forum are placed in the same position. This is done to ensure participation in the process of collaborative cooperation because the existence of the value of negotiating deliberations among each interest is something that supports the success of collaborative governance (Hartz-Karp, 2013, p. 2347).

\section{B. Trust Building}

Trust between stakeholders is one important thing that must exist in a collaboration process. The many parties involved and the diverse backgrounds of stakeholders also support the importance of efforts to trust building. Stakeholder trust is related to past conditions that occurred before the formation of the SATRIA CSR Forum. A large number of businesses that have not yet channeled company CSR funds as well as corporate CSR activities that have not been integrated with local government programs have contributed to the importance of building trust with companies so that CSR programs implemented can involve the SATRIA CSR Forum.

Before the SATRIA CSR Forum, the local government did not get a clear report on CSR activities carried out by companies. As a result, CSR activities carried out by companies have the potential to cause buildup in an area and are not in harmony with the local government. Whereas on the other hand, the local government also has limited financial resources that cannot yet be sufficient to solve the problems that exist in Banyumas Regency. That is, through the SATRIA CSR Forum, the local government seeks to involve actors outside the government, in this case, the business world through CSR activities to get involved in solving problems in Banyumas Regency. This is consistent with the proposition made by Bryson \& Crosby (2006, p. 46) which reveals that public policymakers try to cross-sector collaboration when they believe that separate efforts to address common problems have failed or are likely to fail, and cannot be resolved by a single actor. As a result, the government is trying to find other alternatives by inviting stakeholders to get involved in solving existing problems. Thus, the formation of the SATRIA CSR Forum by the Banyumas Regency Government can be seen as an appropriate effort, due to the government's limitations in solving various existing problems.

Seeing these conditions, it is important to make efforts to build trust with various stakeholders. The Chairman of the CSR Forum has an important role in building trust within the board. These efforts are carried out through internal coordination meetings that are held routinely and discuss transparently the agenda or program, as well as problems that exist in internal governance. Meyer (2014, p. 9) revealed that one of the steps that can be taken to increase trust comes from the focus of group meetings and social activities. That is, the efforts taken by the CSR Forum in building trust with various parties in the internal governance through regular meetings is the right step. The company visit activity is also a form of effort undertaken by the CSR Forum in building business confidence in the existence of the SATRIA CSR Forum. In this case, the existence of the chairman and coordinator of the public relations field becomes the main motor in building the confidence of the business world in Banyumas Regency.

This illustration shows that the face-to-face dialogue activities in a collaborative process are closely related to the effort to build trust so that the company visit carried out at the beginning of the CSR Forum governance is a progressive effort. However, ongoing efforts are needed in building trust in the business world so that they are truly involved in carrying out CSR activities. This is in line with the theory of collaborative governance which states that the effort to build trust is a commitment that requires a long term to truly develop trust (Ansell \& Gash, 2007, p. 559). Therefore, company visit activities that have been carried out at the beginning of the governance need to be followed up with other activity agendas to truly foster the confidence of the business world. The results of research conducted by Hendrayani \& Hashim (2018, p. 140) also found that sustainable face-to-face dialogue is used as a strategic tool in communication systems to achieve mutual trust and mutual understanding to create strong synergies between government, the corporate sector, and the community to achieve sustainable development. Bryson \& Crosby (2006, p. 48) also revealed that cross-sector collaboration becomes more likely to succeed when trust-building activities are carried out continuously. The description shows that in the 
governance of the SATRIA CSR Forum in Banyumas, there is a link between face to face dialogue and efforts to build trust.

\section{Commitment to the Process}

The presence of the SATRIA CSR Forum in Banyumas Regency is based on the interdependence of parties. This dependence can be seen from the 'benefits' reaped by each party after the collaboration, i.e.:

1. The existence of the SATRIA CSR Forum in Banyumas Regency makes the needs of local governments that have not yet received a budget from the APBN or APBD to continue running through collaboration with the CSR Forum. In this case, it is also seen that the local government is the most interested actor in the SATRIA CSR Forum.

2. The existence of the SATRIA CSR Forum provides benefits to the business world in terms of the publication of CSR activities carried out by the company becoming more widely known to the public, so that the good image of the company also increases. The company also has good communication media with the community through CSR activities.

3. NGOs and CBOs benefit from knowing that companies are serious in helping the community, by the role of NGOs and CBOs in the CSR Forum, which is to bridge the interests of the community.

4. The mass media incorporated in the CSR Forum feel the benefits of a wider relationship and increased public knowledge about the existence of the media.

5. Academic needs related to ideas for research service activities are also felt in terms of academics.

The description shows that the CSR Forum is a forum for various parties to collaborate and achieve a win-win solution. Nevertheless, there are still parties in the SATRIA CSR Forum which so far have not felt helped but remain committed in the SATRIA CSR Forum. This shows that the reason for being involved in the CSR Forum is not only for the benefit of the company or organization. But other interests also underlie stakeholders to be involved, one of which is the common vision and mission of the organization with the CSR Forum to bridge the interests and awareness of the objectives of equitable development in Banyumas Regency. This is consistent with research conducted by Mukhlis (2017, p. 157) who found that different motives for profit in collaboration are not always a threat as long as the differences are not mutually negating. Therefore, even though the organization does not feel helped, there are a common vision and mission for the welfare of the community, various stakeholders who have not felt helped remain willing to be involved in the SATRIA CSR Forum.

The interdependence of stakeholders in the SATRIA CSR Forum also supports shared ownership which is manifested in the responsibilities carried out by stakeholders. The regional government has the responsibility to convince the company and has a role in providing the data needed by the company so that the CSR program implemented by the company can be right on target for the community. Stakeholders who have a public relations background carry out their responsibilities in the forum through outreach, either directly through company visits or indirectly through social media. The chairman of the forum has a good commitment and has a very strategic role in building trust. If this can be maintained, it has the potential to support the success of the collaborative process in the SATRIA CSR Forum. As stated by Bryson \& Crosby (2006, p. 52) that the challenges of leadership in crosssectoral cooperation can be seen as the challenges of aligning initial conditions, processes, structures, governance, needs and constraints, results, and accountability.

The presence of multi-stakeholders in the SATRIA CSR Forum made openness between stakeholders become one of the principles that had been implemented in the SATRIA CSR Forum. This is demonstrated through the disclosure of information provided to all governance. Even though some forum administrators do not attend the meeting, the information is still shared with all officials. The Whatsapp Group is also one of the media used by the committee to exchange information with various parties involved in the SATRIA CSR Forum. Also, there is openness to the needs of each party to be bridged through the CSR Forum, including the needs of local governments. This is supported by articles written by Pribadi (2016, p. 104) which state that information disclosure is the key to fostering trust in the collaborative process.

Nevertheless, openness to external parties through social media, which can be utilized for the existence of the forum so that it is known by the public, has not been maximally utilized. Social media is also one of the media that can be used to provide extensive information to the public so that it can encourage the confidence of many parties towards the SATRIA CSR Forum. Following an article was written by Kumar \& Singh (2014, p. 343) which states that social media is an extension of a real-world communication strategy by enabling 
increased transparency and increased interaction between companies and stakeholders.

\section{Shared Understanding}

Although there is potential to support the success of the SATRIA CSR Forum going forward, during the one-year governance period it can be seen that there are obstacles in the collaborative process of the SATRIA CSR Forum in Banyumas Regency, namely:

1. The involvement of private parties to involve CSR Forums in companies' CSR activities is still minimal. So far, although many companies have carried out CSR activities, they are still carried out individually by the company. Reports on corporate CSR activities in the form of notifications to CSR Forums so that CSR Forums can oversee CSR activities from the business world are also not fully understood by companies in Banyumas Regency. In fact, in Banyumas Regent Regulation Number 77 of 2017 on the Governance of Corporate Social Responsibility (TSP) has clearly stated the obligations of the business community to be involved in CSR Forum activities, both in conveying the company's CSR plans and budgets to local governments through CSR Forums, paying attention to the regional development policies, collaborating with local governments and communities, and reporting the realization of CSR activities to local governments.

2. The committee's busy schedule makes the commitment of the governance in the coordination meeting activities not maximized because it cannot be attended by all committee.

3 . The commitment of local governments to participate in the collaboration process is also a note of obstacles. Many OPDs did not attend the meeting scheduled by the CSR Forum, even though the presence of the CSR Forum was to help the existing problems but could not yet be resolved by the OPD.

The description above illustrates that the confidence of the business community towards CSR Forums is one of the keys to success in CSR Forums. One of the causes of the lack of involvement of the business world is that there is a lack of understanding of the business world related to CSR regulations, as well as the absence of incentives provided by the government for businesses that are devoted to carrying out CSR activities. Banyumas Regent Regulation Number 77 of 2017 regarding Governance of Corporate Social Responsibility
(TSP) in article 8 states that the company's obligations, namely compiling program designs that are integrated with various stakeholders to reporting program results to the Banyumas Regency Government.

Seeing this, without the involvement of the business community, the CSR Forum cannot carry out its role in coordinating CSR programs with the regional development agenda. With the involvement of multi-stakeholders, it can encourage the creation of equitable development in Banyumas Regency. In this case, the Government of Banyumas Regency needs to make efforts in providing an understanding of regulation to the business world. Other efforts that can be done are by giving rewards to the business world who are obedient in implementing CSR under regulations, as well as providing punishments for businesses that are not implementing it.

\section{E. Intermediate Outcomes}

The presence of multi-stakeholders in the SATRIA CSR Forum made the output of activities carried out quite varied, ranging from improving RTLH, action on health services, SMEs training, as well as providing playgrounds and education facilities for children. This is one of the benefits of a collaborative approach to introducing various types of concepts that bridge a process, especially between the public and private sectors, where diverse interests and needs are resolved through dialogue and collaborative processes. Even so, when linked to the catalog of the SATRIA CSR Forum program in 2018, the output is still far from expected. Of the 52 programs that have been compiled and planned for various fields, the activities that have been carried out only touch 2 planned programs, namely improvement of the RTLH and action on health services. The activity also did not meet the targeted amount. Seeing this, various parties were not satisfied with the performance of the SATRIA CSR Forum. This is related to the ability of CSR Forums in responding to various problems that exist in the community that has not been maximized because not many companies want to join. Whereas stakeholders' satisfaction is also important in the sustainability of the existing collaborative processes. Ansell \& Gash (2007, p. 561) explain that interim results in the form of small wins can provide feedback in a collaborative process that can encourage a good cycle in building trust and commitment. Nevertheless, the stakeholders involved in the SATRIA CSR Forum have a view on the good potential of the SATRIA CSR Forum going forward. At present, a collaboration scheme has been made between the CSR Forum and the

\section{Collaborative Governance in Corporate Social Responsibility Forum


company, such as:

1. Facilitation scheme. In this scheme, companies that have CSR programs can, through CSR Forum facilitation, provide CSR assistance to recipients.

2. Independent scheme. In the independent scheme, the company must carry out its CSR, CSR Forum only gets a clear report on the activities.

3. Cooperation with third parties. In this scheme, the CSR Forum proposes activities that are carried out with third parties.

With this scheme, it is hoped that all businesses in Banyumas Regency can channel CSR activities by the needs of the government and the community as well as the company's capabilities. If this can be carried out, then all of the company's CSR activities can be monitored by the SATRIA CSR Forum to realize equitable development in Banyumas Regency.

Based on the discussion above, if the governance of the SATRIA CSR Forum in Banyumas Regency is linked with a collaborative governance perspective, it can be seen that there is good potential regarding the existence of the SATRIA CSR Forum in supporting equitable development in Banyumas Regency by involving many parties. However, the low level of stakeholders' commitment and the lack of understanding of the business community regarding CSR regulations has reduced the degree of collaboration in the governance of the SATRIA CSR Forum in Banyumas Regency. Similar research conducted by Sururi (2018, p. 34) also found that process commitment and results are the priority and strategic issues that must be carried out in the collaborative governance process. This conclusion is supported by the success of the CSR Forum collaboration process in West Java, where one of the factors that influenced this success was motivation and commitment (Hendrayani \& Hashim, 2018, p. 146). In the governance of the SATRIA CSR Forum in Banyumas Regency, the lack of commitment impacts the output of activities carried out by the SATRIA CSR Forum to a minimum.

\section{Conclusion}

Based on these results and discussion, this study concludes that the governance of the SATRIA Corporate Social Responsibility Forum (CSR Forum) in Banyumas Regency in the perspective of collaborative governance shows a good stage but has not yet run optimally. This can be seen from the face-to-face dialogue activities carried out that have good potential to support the collaborative process internally, but the stakeholders' commitment that has not been maximized has reduced the degree of collaboration in the SATRIA CSR Forum in Banyumas Regency. Face to face dialogue also has close links with efforts to build trust, especially company visit activities to the business world. Therefore, efforts to build trust must be carried out continuously so that trust can truly grow to its full potential. SATRIA CSR Forum in Banyumas Regency is a media to bring together various interests of various stakeholders to achieve a win-win solution because of interdependence. Therefore, the shared vision shared by various stakeholders in the CSR Forum is one of the commitments to achieve common goals through the SATRIA CSR Forum. In this case, the chairman of the forum has a large role in building commitment to internal governance. Besides, local governments, forum leaders, and public relations also have a strategic role in inviting businesses to be involved in the SATRIA CSR Forum. This is because the understanding of the business world on existing regulations, especially in relations to Banyumas Regent Regulation Number 77 of 2017 on the Governance of Corporate Social Responsibility (TSP), which requires the involvement of the business community in CSR Forum activities, is not fully understood. Even though the regulation has set in detail about the procedures of the business world in implementing CSR ranging from planning to reporting activities. Things that can be done by local governments include the reward mechanism for businesses that have good participation and provide punishment for businesses that do not want to be involved.

\section{ACKNOWLEDGMENT}

The author realizes that the process of completing this research is inseparable from the help and support of various parties. Therefore, the authors express their gratitude to Bank Indonesia for providing the opportunity to the author as the recipient of a 2018 Bank Indonesia scholarship to support the funding of this research. The author also expresses his gratitude to all informants who are willing to provide the information and data needed in this study, namely the Banyumas Regency Government, SATRIA CSR Forum administrators, as well as other parties who cannot be mentioned one by one.

\section{REFERENCES}

Aldrich, D. P., \& Meyer, M. A. (2014). Social Capital and Community Resilience. American Behavioral Scientist, 1-16. https://doi. org/10.1177/0002764214550299 
Ansell, C., \& Gash, A. (2007). Collaborative Governance in Theory and Practice. Journal of Public Administration Research and Theory, 543-571. https://doi.org/10.1093/jopart/ mum032

Azzahra, M. H. (2016). Masih Banyak Permasalahan dalam Pelaksanaan CSR Perusahaan. Retrieved June 11, 2019, from SWA - Trends - Business Research website: https://swa.co.id/swa/ trends/business-research/masih-banyakpermasalahan-dalam-pelaksanaan-csr

Bryson, J. M., \& Crosby, B. C. (2006). The Design and Implementation of Cross-Sector Collaborations: Propositions from the Literature. Public Administration Review, 66(December). https:// doi.org/10.1111/j.1540-6210.2006.00665.X

Ervianti, M. (2018). FAKTOR-FAKTOR YANG MENGHAMBAT COLLABORATIVE GOVERNANCE DALAM IMPLEMENTASI MANAJEMEN DAN REKAYASA LALU LINTAS DI KOTA PEKANBARU. JOM FISIP, 5, 1-13. Retrieved from https://jom.unri.ac.id/index. php/JOMFSIP/article/view/20434

Gallagher, M., \& Hartz-Karp, J. (2013). The Role of Deliberative Governance in Achieving Sustainable Cities. Sustainability, 5, 23432366. https://doi.org/10.3390/su5062343

Hakim, M. L. (2013). Integrasi CSR dan Program Perencanaan Pembangunan Daerah dalam Kerangka Mewujudkan Model Baru Pelaksanaan CSR. Sawala: Jurnal Administrasi Negara, 2. https://doi.org/10.30656/sawala. v2i2.510

Hendrayani, Y., \& Hashim, N. H. (2018). Social Partnership CSR Forum on Sustainable Development, Jawa Barat Indonesia. International Journal of Multicultural and Multireligious Understanding, 5(1999), 140-150. https://doi.org/10.18415/ijmmu. v5i3.276

Hjern, B., \& Porter, D. O. (1981). Implementation Structures: A New Unit of Administrative Analysis. SAGE Journals, 2(3). https://doi. org/10.1177/017084068100200301

Humas PMK. (2015). CSR Perkuat Upaya Pemerintah Mengentaskan Kemiskinan. Retrieved September 21, 2018, from https://www. kemenkopmk.go.id/artikel/CSR-perkuatupaya-pemerintah-mengentaskan-kemiskinan

Kumar, D., \& Singh, P. (2014). SOCIAL MEDIA: NEW CHALLENGES FOR CORPORATE GOVERNANCE. International Journal of Research (IJR), 1(4), 343-352. Retrieved from http://internationaljournalofresearch.org/ index.php/ijr/article/download/71/53/
Lamo, S. A. (2017). Corporate Social Responsibility in Perspective of Public Administration (A Governance Study). ILIRIA International Review, 7(1). https://doi.org/10.21113/iir. v7i1.300

Machmud, S. (2015). Kajian Pemanfaatan Dana Corporate Social Responsibility Sebagai Alternatif Sumber Pembiayaan Pembangunan Daerah. Jurnal Ekonomi, Bisnis \& Entrepreneurship, 9, 29-44. Retrieved from http://jurnal.stiepas.ac.id/index.php/jebe/ article/view/108

Miles, M. B., Huberman, A. M., \& Saldana, J. (2014). Qualitative Data Analysis: A Methods Sourcebook (3rd ed.). United States of America: SAGE Publications, Inc.

Moleong, L. J. (2015). Metodologi Penelitian Kualitatif. Bandung: PT Remaja Rosdakarya.

Mukhlis, M. (2017). ANALISA KRITIS ATAS MOTIF POLICY COMMUNITY DALAM KOLABORASI (Studi Kasus Kebijakan Pemindahan Pusat Pemerintahan Provinsi Lampung). Jurnal Agregasi, 5, 135-158. https://doi. org/10.34010/AGREGASI.V5I2.443

Rasche, A. (2010). Collaborative Governance 2.0. Social Studies Building, 10(4), 500-511.https:// doi.org/10.1108/14720701011069713

Sambodo, G. T., \& Pribadi, U. (2016). Pelaksanaan Collaborative Governance di Desa Budaya Brosot, Galur, Kulonprogo, DI. Yogyakarta. Journal of Governance and Public Policy, 3. https://doi.org/10.18196/jgpp.2016.0052

Suara Merdeka. (2018). Baru 2\% Dunia Usaha Terlibat Program CSR. Retrieved February 26, 2018, from Suara Merdeka 24 Februari 2018 website: https://www.suaramerdeka.com/ smcetak/baca/68328/baru-2-dunia-usahaterlibat-program-csr

Sururi, A. (2018). Collaborative Governance Sebagai Inovasi Kebijakan Strategis (Studi Revitalisasi Kawasan Wisata Cagar Budaya Banten Lama). Humanika, 25(1). https://doi.org/10.14710/ humanika.v25i1.18482

Zaidi, H., Surya, R. Z., \& Juslan. (2016). Analisa Strategi dan Sinkronisasi CSR dengan Program Pemerintah dalam Pembangunan Kabupaten Indragiri Hilir. Jurnal BAPPEDA, 2(1), 242-249. Retrieved from https://ojs.selodangmayang. com/index.php/bappeda/article/view/13

Zain, Q. (2015). Collaboration Strategy dalam Implementasi Corporate Social Responsibility (CSR): Studi Kasus Aqua Danone Klaten. Jurnal Hubungan Internasional, 8(2), 81-98. Retrieved from http://journal.unair.ac.id/ download-fullpapers-jhi8835eaa814full.pdf

\section{Collaborative Governance in Corporate Social Responsibility Forum

